\title{
Neoechinorhynchus (Neoechinorhynchus) zabensis sp. n. (Acanthocephala: Neoechinorhynchidae) from freshwater fish in northern Iraq
}

\author{
Omar M. Amin ${ }^{1}$, Shamall M.A. Abdullah ${ }^{2}$ and Furhan T. Mhaisen ${ }^{3}$ \\ ${ }^{1}$ Institute of Parasitic Diseases, P.O. Box 28372, Tempe, AZ 85285-8372, USA; \\ ${ }^{2}$ Department of Biology, College of Education, University of Salahaddin, Erbil, Iraq; \\ ${ }^{3}$ Department of Biology, College of Education (Ibn Al-Haitham), University of Baghdad, Baghdad, Iraq
}

Key words: Acanthocephala, Neoechinorhynchidae, Neoechinorhynchus zabensis, Capoeta damascina, Capoeta trutta, Zab River, Iraq

\begin{abstract}
Neoechinorhynchus (Neoechinorhynchus) zabensis sp. n. (Acanthocephala: Neoechinorhynchidae) is described from Capoeta damascina (Valenciennes, 1842) (type host) and Capoeta trutta (Heckel, 1843) in the Greater and Lesser Zab Rivers, northern Iraq. The new species is unique among all other species of the genus by its characteristic paired para-vaginal muscular appendage and fragmented giant nuclei in the lemnisci. Eleven of the other 88 valid species of Neoechinorhynchus and $N$. zabensis have middle and posterior hooks of equal length. However, N. zabensis is distinguished from the others by size of trunk, proboscis, proboscis hooks and lemnisci, number of giant nuclei, position of female gonopore, and geographical and host distribution. It is also distinguished from six other species of Neoechinorhynchus previously reported from Iraq. Other distinguishing features are also included.
\end{abstract}

Amin (2002) studied 107 species of Neoechinorhynchus, recognised 88 to be valid, and created 2 subgenera, Hebesoma Van Cleave, 1928 and Neoechinorhynchus Stiles et Hassall, 1905 that differ in egg anatomy. The new species, Neoechinorhynchus zabensis sp. n., belongs in the latter subgenus. It is the 89th species of the genus and second species of Neoechinorhynchus recorded in northern Iraq. The other species is N. rutili (Müller, 1780) found in the Tigris River at Mosul City (Fattohy 1975) and in Dokan Lake (Abdullah 1990). It is the seventh freshwater species of the genus reported in Iraq (Amin et al. 2001). It is herein described and distinguished from other species of the genus.

\section{MATERIALS AND METHODS}

A total of 691 cyprinid fishes of two species were collected from the Lesser Zab River near Alton Kupri City (3436'0'N, $\left.43^{\circ} 46^{\prime} 0^{\prime \prime} \mathrm{E}\right) 45 \mathrm{~km}$ south of Erbil City, and from the Greater

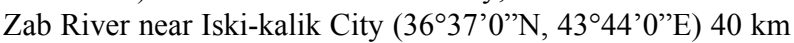
west of Erbil City in northern Iraq (Table 1). Fish were collected by gill netting, cast netting, or electrofishing twice monthly between November 2000 and October 2001. Freshly collected fish were examined for parasites in the laboratory shortly after capture. The names of fishes are according to Froese and Pauly (2003).

Acanthocephalans recovered were first washed in saline solution, refrigerated in cold water for $12 \mathrm{~h}$, then fixed in $70 \%$ ethanol. Worms were stained in Mayer's acid carmine, dehydrated in ascending concentrations of ethanol, cleared in graduated concentrations of terpineol in $100 \%$ ethanol and whole-mounted in Canada balsam. The measurements (in micrometres unless otherwise stated) are given as range followed by mean (in parentheses). Width measurements refer to maximum width. Body (= trunk) length does not include neck, proboscis or bursa. Egg measurements were made of fully developed ripe eggs artificially released from female body cavity. Drawings were made using a Ken-A-Vision microprojector. Type specimens were deposited in the United States National Parasite Collection (USNPC), Beltsville, MD, USA and in the Institute of Parasitology, Academy of Sciences of the Czech Republic (IP), in České Budějovice, Czech Republic.

\section{RESULTS}

The prevalence of acanthocephalan infections in $\mathrm{Ca}$ poeta damascina (Valenciennes, 1842) from both collecting sites was about twice as high as that in Capoeta trutta (Heckel, 1843) but the intensity was about the same (Table 1). Over 10,000 worms were collected from both host species in both localities of which 113 sexually mature specimens (52 males and 61 females) were used for this study.

\section{Neoechinorhynchus zabensis sp. n.}

Figs. 1-7

General. Neoechinorhynchidae, Neoechinorhynchinae with characters of the genus and subgenus NeOechinorhynchus. Trunk medium, cylindrical with sexual dimorphism in size of all common structures. Trunk with thick walls not dorso-ventrally distinguished 

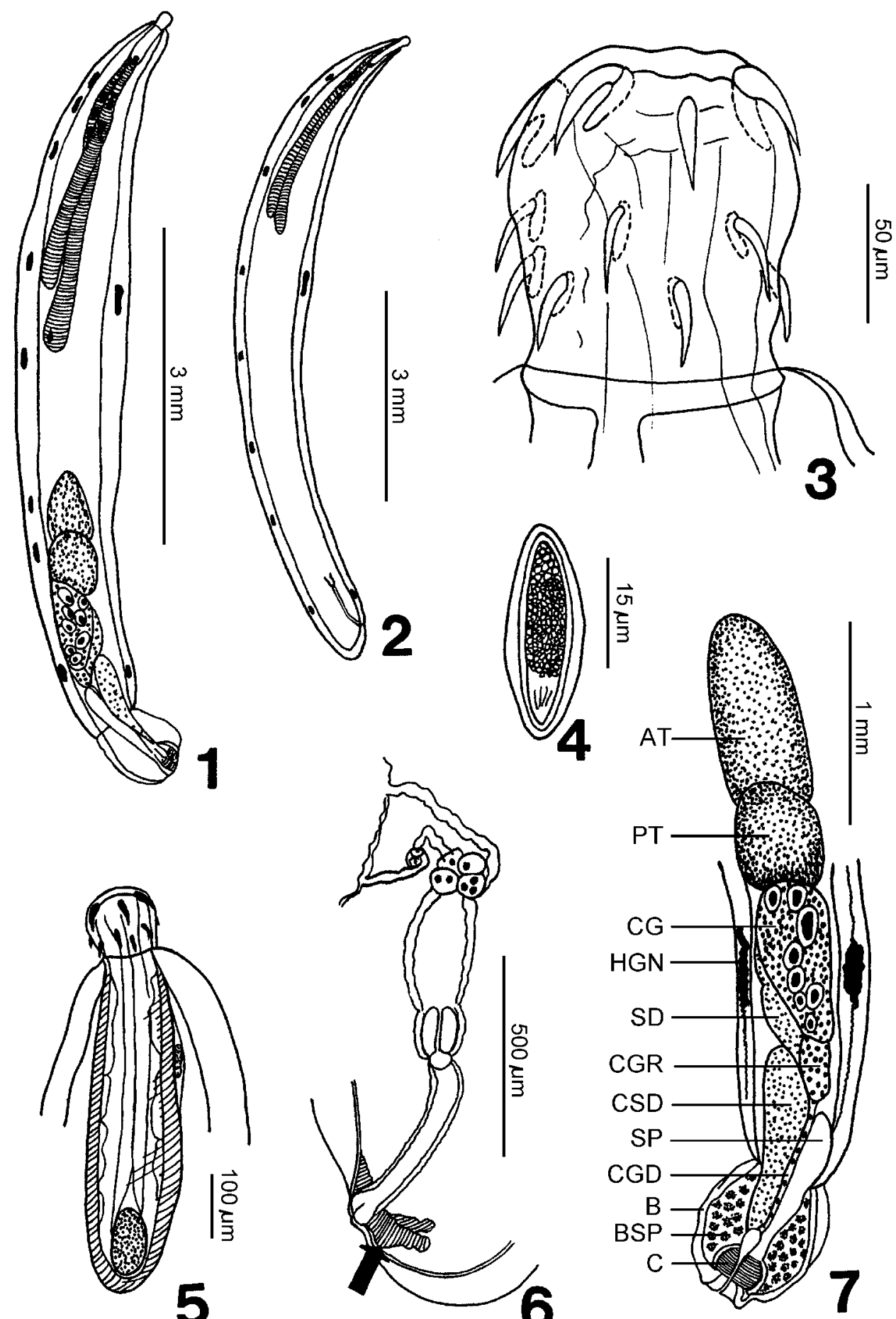

Figs. 1-7. Neoechinorhynchus ( N. ) zabensis sp. n. from Capoeta damascina. Fig. 1. Holotype male. Note nuclear fragments in lemnisci. Fig. 2. Allotype female. Fig. 3. Proboscis of a paratype female. Note two alternating levels of largest hooks in anterior circle. Fig. 4. Mature egg. Fig. 5. Proboscis and receptacle of a paratype female. Note oblong structure trapped under outer cell layer of proboscis receptacle. Fig. 6. Reproductive system of a paratype female with bent uterine bell. Note the paired muscular para-vaginal appendage (arrow) and the sinuate nature of membranes. Fig. 7. Reproductive system of a paratype male. AT anterior testis; B - bursa; BSP - bursal sensory papillae; C - cirrus; CG - cement gland; CGD - cement gland duct; CGR cement gland reservoir; CSD - common sperm duct; HGN - hypodermal giant nuclei; PT - posterior testis; SD - sperm duct; SP - Saefftigen's pouch. 
Table 1. Parameters of infection of Neoechinorhynchus zabensis sp. $n$. in Capoeta damascina and C. trutta from the Zab River, between November 2000 and October 2001.

\begin{tabular}{|l|c|c|c|c|}
\hline & \multicolumn{2}{|c|}{ Capoeta damascina } & \multicolumn{2}{c|}{ Capoeta trutta } \\
& $\begin{array}{c}\text { Greater } \\
\text { Zab River }\end{array}$ & $\begin{array}{c}\text { Lesser } \\
\text { Zab River }\end{array}$ & $\begin{array}{c}\text { Greater } \\
\text { Zab River }\end{array}$ & $\begin{array}{c}\text { Lesser } \\
\text { Zab River }\end{array}$ \\
\hline Fish length (cm) & $7-42(28)$ & $6-33(25)$ & $7-45(26)$ & $9-45(25)$ \\
No. fish examined & 300 & 192 & 21 & 178 \\
No. fish infected & 280 & 179 & 7 & 85 \\
Prevalence (\%) & 93.3 & 93.2 & 33.3 & 47.7 \\
Parasites/fish (mean) & $0-42(20)$ & $0-28(16)$ & $0-30(14)$ & $0-30(18)$ \\
\hline
\end{tabular}

having 7-11 (usually 8-10) dorsal and 1-3 (usually 2) ventral hypodermal giant nuclei (Figs. 1, 2). Proboscis as long as wide; apical organ not prominent. Proboscis hooks in all circles rooted. Anterior hooks largest alternating at two levels, with somewhat curved simple roots without manubria. Hooks in second and third circles slightly shorter than anterior hooks and have roots with reduced anterior manubria. Hooks in second circle as long as hooks in third circle but more slender (Fig. 3). Neck unremarkable. Proboscis receptacle about 6 times as long as proboscis, with single muscular wall having usually two small oblong structures "trapped" just under its outer cell layer in its anterior half. Cerebral ganglion (brain) large, oval, about as long as proboscis, at base of receptacle (Fig. 5). Lemnisci subequal, ribbon-shaped, widest posteriorly, distant from anterior testis and corresponding distance in females, 5 or 6 times as long as proboscis receptacle, with 2-4 (usually 3) and 1-3 (usually 2) giant nuclei in the longer and shorter lemniscus, respectively; one or more nuclear fragments also present in posterior half of either lemniscus (Figs. 1,2).

Male (based on 18 mature specimens with sperm). Trunk 5.07-10.12 (7.42) mm long by $0.85-1.50(1.12)$ $\mathrm{mm}$ wide. Proboscis $88-125$ (107) long by $100-112$ (106) wide. Proboscis hooks in anterior circle 37-45 (42) long; in middle circle 30-35 (33) long; in posterior circle 30-35 (33) long. Proboscis receptacle 426-728 (566) long by 125-187 (150) wide. Longer lemniscus $2.00-3.75$ (2.97) $\mathrm{mm}$ long by $0.12-0.27(0.20) \mathrm{mm}$ wide posteriorly; shorter lemniscus 1.55-3.30 (2.63) mm long by $0.15-0.27(0.18) \mathrm{mm}$ wide posteriorly. Reproductive system in posterior half of trunk and extends to posterior end of bursa (Fig. 7). Testes oblong, approximately equal in size, usually slightly overlapping with each other and contiguous with cement gland. Anterior testis $0.50-1.32(0.88) \mathrm{mm}$ long by $0.40-0.75(0.54) \mathrm{mm}$ wide; posterior testis $0.50-1.30(0.88) \mathrm{mm}$ long by 0.35-0.75 (0.49) mm wide. Cement gland large, tapering posteriorly, $0.35-1.20(0.73) \mathrm{mm}$ long by $0.27-0.65$ $(0.40) \mathrm{mm}$ wide anteriorly, with 8 vesicular giant nuclei, contiguous to cement gland reservoir 175-400 (278) long by 125-250 (179) wide. Cement gland duct runs between Saefftigen's pouch 0.52-1.02 (0.73) mm long by $0.10-0.21(0.15) \mathrm{mm}$ wide and large common sperm duct $0.60-1.25(0.90) \mathrm{mm}$ long and $0.10-0.35(0.25)$ $\mathrm{mm}$ wide. Bursa 375-925 (648) long by 350-825 (570) wide, with many sensory papillae, designed to accommodate posterior reproductive structures including prominent cirrus (Fig. 7).

Female (based on 18 gravid specimens). Trunk 8.8214.87 (10.87) $\mathrm{mm}$ long by $0.97-2.12$ (1.46) $\mathrm{mm}$ wide. Proboscis 100-125 (112) long by 100-122 (112) wide. Proboscis hooks in anterior circle 37-46 (42) long, in middle circle 30-40 (35) long, in posterior circle 30-40 (35) long. Proboscis receptacle 510-728 (593) long by 135-198 (170) wide. Longer lemniscus 3.10-4.35 (3.67) $\mathrm{mm}$ long by $0.10-0.31(0.25) \mathrm{mm}$ wide; shorter lemniscus $2.90-4.12$ (3.37) mm long by $0.10-0.31(0.23) \mathrm{mm}$ wide. Reproductive system with sinuate membranes, distal vaginal swelling, markedly subterminal gonopore, uterus and uterine bell as long as vagina, and one paired muscular para-vaginal appendage (Fig. 1). Eggs ovoidelongate with concentric shells 28-35 (30) long by 10 17 (14) wide (Fig. 4).

T y p e h o s t: Capoeta damascina (Valenciennes, 1842) (Cyprinidae).

O the r host: Capoeta trutta (Heckel, 1843) (Cyprinidae). Site of infection: Intestine.

$\mathrm{T}$ y p e 1 o c a 1 i t y: Greater Zab River near Iski-kalik City (36³7'0'N , 43⒋'0'E) $40 \mathrm{~km}$ west of Erbil City, northern Iraq.

O t h e r 1 o c a 1 i t y : Lesser Zab River near Alton Kupri City (343'ㅇ' $\left.\mathrm{N}, 43^{\circ} 46^{\prime} 0^{\prime \prime} \mathrm{E}\right) 45 \mathrm{~km}$ south of Erbil City, northern Iraq.

S p e c i m e n s d e p o s i t e d : USNPC 92390 (holotype male), 92391 (allotype female), 92392 (paratypes on 14 slides); IP A-77 (paratypes on 3 slides).

E t y m o lo g y: The new species is named for the Zab River in which it is found.

\section{DISCUSSION}

Neoechinorhynchus (N.) zabensis is distinguished from all other species of the genus by having a paired muscular para-vaginal appendage. We found no records of nuclear fragments in the lemnisci or the structure present in the proboscis receptacle wall in the description of any of the other 88 species of the genus. 
Table 2. Comparison between Neoechinorhynchus zabensis sp. n. and the 11 other species of Neoechinorhynchus with equal middle and posterior proboscis hooks, based on Amin (2002).

\begin{tabular}{|c|c|c|c|c|c|c|c|c|c|c|}
\hline Species* & $\begin{array}{c}\text { Trunk L (mm) } \\
\text { MM, FF }\end{array}$ & $\begin{array}{c}\text { Proboscis } \\
\mathrm{L} \times \mathrm{W}\end{array}$ & $\begin{array}{l}\text { Proboscis } \\
\text { hooks L }\end{array}$ & Lemnisci & $\begin{array}{l}\text { Para-vaginal } \\
\text { appendage }\end{array}$ & hypodermal & $\begin{array}{l}\text { Giant nuclei } \\
\text { lemniscal }\end{array}$ & cement gland & Female gonopore & Distribution \\
\hline $\begin{array}{l}\text { N. armenicus } \\
\text { Mikailov, } 1975\end{array}$ & $9-25$ & $\begin{array}{l}160-200 \times \\
130-180\end{array}$ & $\begin{array}{l}60-74 \\
33-41 \\
33-41 \\
\end{array}$ & equal & absent & NG & NG & NG & NG & Armenia \\
\hline $\begin{array}{l}\text { N. bangoni } \\
\text { Tripathi, } 1956\end{array}$ & $9-12,15-20$ & $\begin{array}{l}76-118 \times \\
89-106\end{array}$ & $\begin{array}{l}26-38 \\
19-23 \\
19-21 \\
\end{array}$ & $\begin{array}{c}\text { markedly } \\
\text { unequal }\end{array}$ & absent & NG & NG & NG & NG & India \\
\hline $\begin{array}{l}\text { N. golvani } \\
\text { Salgado- } \\
\text { Maldonado, } 1978\end{array}$ & $1,1-3$ & $\begin{array}{l}56-75 \times \\
56-75\end{array}$ & $\begin{array}{c}45-78 \\
18 \\
18\end{array}$ & subequal & absent & 5,1 & NG & NG & terminal & Mexico, Brazil \\
\hline $\begin{array}{l}\text { N. hutchinsoni } \\
\text { Datta, } 1936\end{array}$ & $\begin{array}{c}8,19 \\
\text { constricted }\end{array}$ & $\begin{array}{l}70-100 \times \\
99-110\end{array}$ & $\begin{array}{l}50 \\
37 \\
35\end{array}$ & subequal & absent & 5,2 & NG & NG & NG & India \\
\hline $\begin{array}{l}\text { N. ichthyobori } \\
\text { Saoud, El Naffar } \\
\text { et Abu Sinna, } 1974\end{array}$ & $30-42$ & $100 \times 100$ & $\begin{array}{l}68-84 \\
30-42 \\
30-42 \\
\end{array}$ & subequal & absent & $2-3,3-4$ & 1,1 & $21-24$ & terminal & Sudan \\
\hline $\begin{array}{l}\text { N. ovalis } \\
\quad \text { Tripathi, } 1956\end{array}$ & $0.725,0.652$ & $114 \times 91$ & $\begin{array}{l}60-68 \\
53 \\
53\end{array}$ & equal & absent & 4,2 & NG & NG & NG & India \\
\hline $\begin{array}{l}\text { N. plagiognathopitis } \\
\text { Wang et Zhang, } 1987\end{array}$ & 16 & $210 \times 175$ & $\begin{array}{l}66-70 \\
28-35 \\
28-35\end{array}$ & equal & absent & NG & NG & no males & subterminal & China \\
\hline $\begin{array}{l}\text { N. prolixus } \\
\text { Van Cleave et } \\
\text { Timmons, } 1952\end{array}$ & $5-12,7-16$ & $\begin{array}{l}84-112 \times \\
98-140\end{array}$ & $\begin{array}{l}42-56 \\
28 \\
28\end{array}$ & $\begin{array}{c}\text { markedly } \\
\text { unequal }\end{array}$ & absent & 5,1 & 2,1 & 8 & subterminal & North America \\
\hline $\begin{array}{l}\text { N. quinghaiensis } \\
\text { Liu, Yang et } \\
\text { Yang, 1981 }\end{array}$ & $2-4,3-5$ & $\begin{array}{l}69-114 \times \\
63-137\end{array}$ & $\begin{array}{l}35-60 \\
17-27 \\
17-27 \\
\end{array}$ & subequal & absent & 5,1 & 2,1 & few & terminal & China \\
\hline $\begin{array}{l}\text { N. simansularis } \\
\quad \text { Roitman, } 1961\end{array}$ & $9-25$ & $\begin{array}{l}80-108 \times \\
84-104\end{array}$ & $\begin{array}{l}44-60 \\
20-28 \\
20-28\end{array}$ & subequal & absent & $3+, 1$ & 2,1 & NG & NG & Russia \\
\hline $\begin{array}{l}\text { N. tylosuri } \\
\text { Yamaguti, } 1939\end{array}$ & $16-24,21-70$ & $\begin{array}{l}100-160 \times \\
120-150\end{array}$ & $\begin{array}{l}63-75 \\
30-35 \\
30-35\end{array}$ & $\begin{array}{c}\text { markedly } \\
\text { unequal }\end{array}$ & absent & 5,1 & 2,1 & 20 & subterminal & $\begin{array}{l}\text { Japan, } \\
\text { North Pacific }\end{array}$ \\
\hline N. zabensis sp. $\mathrm{n}$. & $5-10,9-15$ & $\begin{array}{l}107-112 \times \\
106-112\end{array}$ & $\begin{array}{l}37-45 \\
30-35 \\
30-35\end{array}$ & subequal & present & $8-10,2-3$ & 3,2 & 8 & subterminal & Iraq \\
\hline
\end{tabular}

*All species are from freshwater fish except N. golvani from estuarine/marine fish, see Amin (2002); MM - male; FF - female; NG - not given. 
Only 11 other species of Neoechinorhynchus have the middle and posterior proboscis hooks of similar length like $N$. zabensis. Distinguishing diagnostic features are summarised in Table 2.

Amin et al. (2001) described N. iraqensis Amin, AlSady, Mhaisen et Bassat, 2001 and Mhaisen (unpublished data) observed five other species of Neoechinorhynchus from freshwater fishes in Iraq: $N$. australis Van Cleave, 1931; N. cristatus Lynch, 1936; N. dimorphospinus Amin et Sey, 1996; N. macronucleatus Machado, 1954; and N. rutili (Müller, 1780). None of these six species has para-vaginal appendage, lemniscal nuclear fragments, cellular structures in the proboscis receptacle wall, or proboscis hooks in second and third circles of equal length as the case is in $N$. zabensis. Other distinguishing differences include: specimens of $N$. iraqensis are very long with laterally constricted proboscis, markedly unequal lemnisci, and terminal female gonopore. Specimens of $N$. australis and $N$. cristatus have markedly unequal lemnisci and a terminal female gonopore with the latter species having proboscis hook roots with anterior manubria, and large eggs. Specimens of $N$. dimorphospinus have proboscides markedly wider than long with unequal hooks in anterior circles and terminal female gonopore, and rounded eggs. Hypodermal giant nuclei of $N$. macronucleatus are bead-like in body wall swelling with anterior four dorsal nuclei being adjacent, lemnisci are equal and female gonopore terminal. Anterior proboscis hooks of $N$. rutili are about twice as long as middle hooks and female gonopore is also terminal. All six species have the usual number of hypodermal giant nuclei (4-6 dorsal, 1-2 ventral; usually 5,1$)$ compared to the usual greater number found in $N$. zabensis of 8-10 dorsal, and 2-3 ventral.

Acknowledgement. We are grateful for Karim Amin's help and support of this and other research projects at the Institute of Parasitic Diseases.

\section{REFERENCES}

ABDULLAH S.M.A. 1990: [Survey of the parasites of fishes of Dokan Lake.] M.Sc. thesis, Coll. Sci., Univ. Salahaddin, Erbil, Iraq, 115 pp. (In Arabic.)

AMIN O.M. 2002: Revision of Neoechinorhynchus Stiles and Hassall, 1905 (Acanthocephala: Neoechinorhynchidae) with keys to 88 species in two subgenera. Syst. Parasitol. 53: $1-18$.

AMIN O.M., Al-SADY R.S.S., MHAISEN F.T., BASSAT S.F. 2001: Neoechinorhynchus iraqensis sp. n. (Acantho- cephala: Neoechinorhynchidae) from the freshwater mullet, Lisa abu (Heckel), in Iraq. Comp. Parasitol. 68: 108-111.

FATTOHY Z.I. 1975: [Studies on the parasites of certain teleostean fishes from the River Tigris, Mosul, Iraq.] M.Sc. thesis, Coll. Sci., Univ. Mosul, Mosul, Iraq, 136 pp. (In Arabic.)

FROESE R., PAULY D. (Eds.) 2003: Fish Base. World Wide Web electronic publication. www.fishbase.org., version 20 June 2003.

Accepted 20 June 2003 